\title{
The changing images of Simone de Beauvoir in Norway
}

\author{
Ida Hove Solberg \\ University of Oslo \\ Postbox 1003 Blindern, 0315 Oslo, Norway \\ Mobile phone: +4791605474 \\ E-mail address: $\underline{\text { i.h.solberg@ilos.uio.no }}$
}

Biographical note: Ida Hove Solberg is a PhD candidate in Translation Studies at the Department of Literature, Area Studies and European Languages at The University of Oslo, in the thematic research area Travelling Texts. Paying particular attention to the impact of the agents involved and their ideological stances, her research explores the interplay between Simone de Beauvoir's Le deuxième sexe in Norwegian translations and the sociocultural context into which it is translated. She is also co-founder and editor of the literary magazine Mellom (Between), Norway's first journal devoted entirely to translation and translated literature.

\begin{abstract}
The ways in which the French author and philosopher Simone de Beauvoir (1908-1986) has been portrayed in Norwegian print media have undergone significant changes since she was
\end{abstract}


first introduced to the Norwegian reading public in the 1940s. But how - and why - did her image evolve? This article explores the interplay between the words and phrases used to depict de Beauvoir in Norwegian print media and her seminal essay Le deuxième sexe (1949) and different translations in Norway. By analysing how de Beauvoir is depicted, I aim to produce a better understanding of her multiple and changing images in Norway, and to show how they may be related to the different translations of her best-known work and to her changing status. The transformation of de Beauvoir - from being considered outdated and dependent on Sartre during the 1940s and 1950s, to being highly valued and recognized as an author and memorialist, significant philosopher and popular feminist icon at the turn of the millennium - is partly a result of the different translations of her major work. At the same time, it could be claimed that her changing image prepared the ground for the translations.

Keywords: Simone de Beauvoir, Norwegian reception, author image, translation.

\section{Introduction}

In 2008, the Norwegian newspaper Dagsavisen asked in its general knowledge quiz: "What is Simone de Beauvoir known as?” (“12 på strak arm”, 2008). The correct answer, "Feminist, author and philosopher", affirms de Beauvoir's status at the centenary of her birth. Such a question being posed in a general knowledge quiz indicates that both her name and her position are part of the public domain in Norway, supposedly known by "everyone". Some fifty, or even forty, years earlier, at the height of her career, this was not the case. When her name first appeared in a Norwegian newspaper (in the Labour Party owned Arbeiderbladet in 1947), she figured as the girlfriend of Jean-Paul Sartre. Even ten years later, when she was presented as an author of literary works, she was always closely related to Sartre and the 
existentialist milieu. What led to her entry into the cultural arena as an author, feminist and philosopher in her own right? By what images was the author depicted during different stages of the process? And how do these images relate to the Norwegian translational history of her most well-known work, Le deuxième sexe (1949)? In this article, I explore four recurring images found in descriptions of de Beauvoir by critics and cultural journalists in Norwegian print media over a period of six decades, from the late 1940s to 2010. These author images change over time, not neatly from one decade to the next, but in an ongoing process and in interplay with different translations of Le deuxième sexe.

In her essay "Reception problems for women writers: The case of Simone de Beauvoir", which examines the French and North-American reception of the author and her work, Elizabeth Fallaize poses the following questions:

In what terms did [de Beauvoir's readers] think of her [...]? Did attitudes change after the publication of Le Deuxième Sexe, as one might surmise? How has her reception, her image as writer, changed over time and is it possible to identify key moments or turning points? Which Beauvoir - Beauvoir the feminist, Beauvoir the novelist, Beauvoir the memorialist - is likely to emerge and why? (Fallaize, 1995, p. 43) Like Fallaize, when I started researching the changing author images of de Beauvoir, I hypothesized that her seminal work, Le deuxième sexe, constituted a turning point in the reception. As I was approaching the topic from a Norwegian perspective, this meant taking into consideration not only de Beauvoir's text in French, but also the two Norwegian translations, the first one published in 1970 and the second in 2000, as well as the Danish translation of 1965. Because there have been different translations, and during the first phase of reception no Scandinavian translation at all, the fact of the matter is that critics and cultural journalists have been responding to different texts at different times. ${ }^{1}$ Consequently, the changing author images of de Beauvoir are here analysed against the background of the 
translations of Le deuxième sexe that were available in Norwegian - and in Danish, since the languages are closely related and there has been much cultural exchange between the two countries (see Solberg, 2016 for a discussion of the relationship between the first Scandinavian translations of Le deuxième sexe). I have divided the Norwegian reception of de Beauvoir into four periods, starting with the early images of the author in Norway (19481964), continuing with her image after being translated into Scandinavian (1965-1974) and during the period leading up to the retranslation (1975-1999), ending with her image after the retranslation (2000-2010).

In brief, this article explores the interplay between de Beauvoir's essay in different translations (or the absence thereof), the recurring images in depictions of de Beauvoir in Norwegian print media, and external factors that have had a re-actualizing effect or have otherwise impacted upon the Norwegian reading public's author image of de Beauvoir. Such external factors are translations (into Norwegian, mostly) of her other works, significant dates (jubilees, her passing), and the work done by academics seeking to have her intellectual achievements and philosophical contributions recognized. By analysing how the author and her work are depicted during the different periods, I aim to produce a better understanding of the multiple and changing images of Simone de Beauvoir in Norway, and their interplay with the different translations of her best-known work, as well as with her changing status in the Norwegian public sphere.

\section{Previous research on receptions of de Beauvoir}

The four main ways of depicting de Beauvoir that I discern in Norwegian print media are: first, Sartre's de Beauvoir; second, de Beauvoir the author; third, de Beauvoir the feminist; and finally, de Beauvoir the philosopher. These bear obvious resemblances to the different "Beauvoirs" listed by Fallaize (1995, p. 43): "Beauvoir the feminist, Beauvoir the novelist, 
Beauvoir the memorialist." Indeed, "Beauvoir the novelist" and "Beauvoir the memorialist" are both to be found in Norwegian print media, but the hypernymous "Beauvoir the author" is by far the most prominent. Furthermore, had Fallaize's essay been written later and thus included the image of de Beauvoir from the turn of the millennium, it is very possible that she would have added "Beauvoir the philosopher" to her list. However, as I will argue, the change in the author's status that asserted the image of de Beauvoir as philosopher was still in process at the time when Fallaize's essay was published.

Fallaize's essay on the reception of de Beauvoir builds in part on Joanna Russ's work How to Suppress Women's Writing (1984). As the title clearly states, Russ presents different strategies for devaluing women artists and their works. One strategy that is particularly relevant to the case in the present article is "false categorizing", i.e. when the artist is removed from her category as artist - or, in this case, author, and instead is defined as the mother, sister or lover of a man. Fallaize claims that, in the case of de Beauvoir, this meant becoming "both the lover and the disciple of Sartre" (Fallaize, 1995, p. 52). Whether this categorizing is indeed "false" or simply reductive is a subject for discussion. In my categorization, this strategy corresponds to the first group of images, which I have called Sartre's de Beauvoir, which comprises different relations, both "true" (such as "friend" or "colleague") and "false" (such as "wife" or "secretary"). By grouping them together, it was my intention to highlight the fact that de Beauvoir was defined by her relation to Sartre regardless of whether the type of relation was true or not.

In Simone de Beauvoir: The Making of an Intellectual Woman (1994), more specifically in the chapter "Politics and the Intellectual Woman: Clichés and Commonplaces in the Reception of Simone de Beauvoir", Toril Moi presents her research on academics' and literary critics' reception of de Beauvoir and her works, identifying the strategies used to devalue the author and her work. According to Moi (1994, p. 77), "It is impossible to read 
much hostile Beauvoir criticism without noticing the recurrence of certain topoi, or commonplaces." Moi's chosen term, topos, is just as relevant an access point to the topic as Fallaizes's "image". However, the way in which Moi uses the term topos stresses the recurrence of the strategies used to devalue de Beauvoir and her work. In this article, I use the term "image", since one of my main concerns is the question of the changing ways in which she has been "portrayed" or "depicted", thus precisely creating different "images" of the author, both positive and less favourable ones.

The personality topos is the one that receives the most attention from Moi, i.e. the reduction of the book to the woman, or the fictional characters to the author:

The critic obsessively returns to the question of femininity [...] passionately discussing Beauvoir's looks, character, private life or morality. The implication is that whatever a woman says, or writes, or thinks is less important and less interesting than what she is. (Moi, 1994, p. 78)

Moi here emphasizes how critics in France and the USA have tended to ignore de Beauvoir's contributions as an intellectual, and rather focused on her person or even her physical appearance. This seems to be a bigger problem in the academic reception in France and the USA than in the public reception in Norwegian print media. In fact, both Moi's and Fallaize's research on the reception of de Beauvoir and Le deuxième sexe are mostly focused on the negative aspects, especially on the personality topos. In contrast to their studies, I have chosen a more global approach, focusing both on the appreciative and less appreciative reception of de Beauvoir and Le deuxième sexe. In fact, de Beauvoir has received much positive attention in Norwegian print media. Focusing solely on the negative reception would thus create a reductive presentation of her reception.

Another difference between the present article and Moi's and Fallaize's studies is that I take into account the fact that much of the reception is indeed a reception of de Beauvoir's 
work in translation. It is interesting to note that, although Fallaize's essay intriguingly explores the role of the author's gender from the point of view of reception research, the essay does not consider the actual text that meets the reader (i.e. the English translation from 1953, The Second Sex) when looking at the North-American reception. ${ }^{2}$ From the perspective of translation studies, I argue that the different texts (that is, the original and the various translations) in fact do create - and are themselves - different responses, engaging in a reciprocal interplay between the translated texts and the author images.

\section{Method and material}

My research has been focused on print media, comprising the daily press, and literary, women's and feminist magazines. The magazines are not digitalized, and I have therefore gone through them manually. ${ }^{3}$ Newspapers have to a certain extent been digitalized in the Norwegian database Retriever, and in the database of the Norwegian National Library, NB Digital, where I conducted my research. ${ }^{4}$ Additionally, I have included in my analysis the newspaper clippings of press reviews found in the publisher's (non-digital) archive at the Norwegian Labour Movement Archives and Library (ARBARK). ${ }^{5}$ I have searched for Beauvoir as well as mentions of Le deuxième sexe in the databases as well as in the nondigitalized material. ${ }^{6}$ For practical reasons, I have refrained from including the medium of television broadcasting or web pages. I have also limited the search by not looking into purely academic publications, as my primary interest lies in de Beauvoir's image among the general public.

Methodologically, I build on Moi (1994) and Fallaize (1995) as I search for the different ways in which de Beauvoir and her work have been described in these print media, noting how it changes over time, and giving illustrative examples from the articles. I add to this the question of translations and how they may affect the author's image. 


\section{Early images of de Beauvoir in Norway: 1948-1964}

Some of the earliest mentions of Simone de Beauvoir in Norwegian print media are found in the literary magazine Vinduet. Here, she is described in a way that suggests that she is already a familiar name to readers, while at the same time she is being defined by her relation to JeanPaul Sartre, as well as Albert Camus and others of the existentialist circle ("Glimt fra Frankrike", 1948). Despite being presented as well known to the readers of Vinduet, de Beauvoir was only mentioned in passing in a notice when she and Sartre travelled in Scandinavia in 1948. The notice states, laconically, one might add, that Sartre travelled with “his 'secretary’ Simone de Beauvoir” (“Dette og Hint”, 1948).

De Beauvoir reappears in Vinduet in 1961, when author and literary scholar Yngvar Ustvedt writes an essay about her first two autobiographies, Mémoires d'une jeune fille rangée (1958) and La force de l'âge (1960) (Ustvedt, 1961). None of de Beauvoir's works were yet translated into Norwegian, so Ustvedt is writing about the French texts, introducing them to Norwegian readers, taking on the role of cultural mediator. This very thorough piece is called "Simone de Beauvoir looks back" and here she is mostly treated as an author and a memorialist in her own right. However, even though she remains in focus in Ustvedt's essay, her relation to Sartre soon becomes defining of her authorship, when Ustvedt points out that her choice of the autobiographical genre is "peculiar" since de Beauvoir has been "the most faithful disciple" of Sartre's littérature engagée.

The image of Sartre's de Beauvoir culminates in the final paragraph of Ustvedt's essay, in which the two are suddenly merged into a plural form. Although de Beauvoir and Sartre are gathered together seemingly as equals, the bare fact that Sartre is mentioned in this way in an article on de Beauvoir's work implies that he occupies a more central position than her, or perhaps that she is even considered inseparable from him. In Ustvedt's (1961, p. 22) 
formulation, "The driving force of their work is a struggle for freedom", 7 and the word "their" appears here despite the fact that hardly any of Sartre's works have been discussed (only $L a$ nausée has been mentioned). Ustvedt's merging of the two authors in this essay about de Beauvoir's autobiographies is similar to what Fallaize, when writing about the early French reception, describes as a focus on "the context of Sartre and existentialism" that was "heavily alluded to in reviews by many [...] critics and writers" (Fallaize, 1995, p. 44).

Despite Ustvedt's mediation of de Beauvoir's autobiographies in French, the image of her throughout the 1950s and early 1960s, particularly in newspapers, is that of Sartre's de Beauvoir. Such is the case when she is wrongfully described as "his wife, the author Simone de Beauvoir", although simultaneously considered: “one of France's most famous female writers" ("Jean-Paul Sartre og frue i Oslo", 1951). In another notice, she is described as "his author friend Simone de Beauvoir" (“Anti-kommunistisk kunstfest i Paris”, 1952). ${ }^{8}$ The most poignant example of this image is a notice from 1958 where Sartre's full name $i s$ the headline, although the notice is actually about de Beauvoir and her first autobiography. This happens because the beginning of the first sentence makes up the headline (headline in italics): "JeanPaul Sartre's friend, travel partner, and close colleague, the author Simone de Beauvoir, has published an autobiography with the ironic title 'Mémoires d'une jeune fille rangée"” (“Jean Paul Sartres", 1958). The effect of this is that, by defining de Beauvoir in terms of her relation to Sartre, a notice about a work by de Beauvoir is in practice disguised as a notice about Sartre.

Standing out in the daily press are articles by the French-born author, journalist and director Nicole Macé (1931-2011), who wrote longer pieces about de Beauvoir in some of the largest and most widely read newspapers in Norway (Morgenbladet, a conservative paper in the 1960s, and the large and popular Verdens Gang - VG, as well as the left-leaning Arbeiderbladet), focusing on de Beauvoir's work as author, memorialist and thinker, offering 
her view on de Beauvoir's work to the reading public. In a feature article from 1961 entitled “An author in search of herself: Simone de Beauvoir's memoirs", Macé asks why none of de Beauvoir's works have been translated into Norwegian. She notes that de Beauvoir's name is well-known in Norway, "at least in connection to Sartre's", but that her literary production is less familiar (Macé, 1961). Macé describes de Beauvoir as “one of France’s most significant thinkers" and "Sartre's closest colleague", as well as a regular writer for Les temps modernes, where "significant excerpts from her grand essay on woman's psyche and position in society as seen from an existentialist point of view: 'Le Deuxième Sexe'” had been published (Macé, 1961). Like Ustvedt, Macé states that, philosophically, de Beauvoir should be considered "a disciple of Sartre's", but she praises her literary style, comparing her portraits of women to the most successful ones by Virginia Woolf, Katherine Mansfield and Colette (Macé, 1961). Macé even points out the sexism in the French reception of Le deuxième sexe, in which: "Characteristically, the male reviewers did not attack the work itself, but the author. [...] A book like that could not be written by a 'normal' woman. Simone de Beauvoir had to be sexually aberrant, frustrated, unloved, envious, etc.” (Macé, 1964).

De Beauvoir's personality and different conceptions of it are also commented upon by Macé, as she argues that de Beauvoir's heartfelt writing about Sartre when he was imprisoned during WWII, in La force de l'âge, perhaps was "not to be expected in the work of a 'cold, intellectual woman"” (Macé, 1961). Macé thus refers to the negative way of describing de Beauvoir's personality. Macé notes that some have considered her to be “deprived of all femininity" and argues that the feelings she shows in her writing about Sartre, "these careful confessions, the deep tenderness and sensitivity they reveal, $[\ldots]$ cast a whole new light on her personality as a woman" (Macé, 1961).

The image of de Beauvoir thus undergoes significant changes in the years leading up to the first translations of her work in Scandinavia. There is a process of moving away from 
portraying her exclusively in relation to Sartre, as Sartre's de Beauvoir, towards also including her own accomplishments as a writer, that is, de Beauvoir the author. Standing out among the depictions of Sartre's de Beauvoir are the writings of Ustvedt and Macé. Ustvedt is more focused on the wider context of existentialism and on coining "Beauvoir the author" and "Beauvoir the memorialist", to use Fallaize's terms. This focus is also what sets Macé's pieces apart from other writings on de Beauvoir in the daily press of this period: the balanced critique and the focus on her as author, memorialist and thinker. However, Macé also sweeps by the personality topos when discussing the author's level of femininity in an attempt to argue against the image of de Beauvoir as a “cold, intellectual woman”. Nevertheless, writings such as Ustvedt's and Macé's undoubtedly played a part in preparing the ground for the translation of her work into Norwegian.

De Beauvoir's image after the first Scandinavian translations of Le deuxième sexe: 19651974

When the first Scandinavian translation of Le deuxième sexe, the Danish Det andet køn, came out in 1965, it received attention even in Norway. This was an almost unabridged version, which is still (in 2017) the only Danish translation there is. A short review of the 1965 translation was printed in the Norwegian feminist journal, NKN's blad, the Norwegian National Women's Council's magazine (associated with the International Council of Women), in which de Beauvoir is described as a "very knowledgeable and well-read lady" who has written a "lengthy" book that is worth reading ("Under leselampen", 1965).

A more extensive review of the Danish translation was written by the French-born Dominican friar Albert Raulin (1919-2003) and published in the large popular newspaper $V G$. Apart from a few cutting comments, Raulin's review is balanced and interesting, particularly in its assessment of the future role and impact of this work. One of Raulin's main points is 
that few readers would actually read the whole book, because it is too long, and too "French" - both in the sense that they will find it too abstract, meticulous and philosophical (as opposed to what he calls "Nordic pragmatism"), and at the same time relates too concretely to what he sees as a specifically French reality (Raulin, 1965). Yet, he insists that the publication is not unnecessary; in fact, he states that it will remain a classic for many people to refer to in the future (Raulin, 1965). He furthermore claims that its value lies in the meticulous and multifaceted exploration of women's situations:

What makes the book valuable is precisely the attributes that will make most readers give up, namely its comprehensiveness and its philosophical foundation. The author attacks the problem of woman's life as it appears in history, in poetry, in religions and in the individual woman's experience, from every possible angle. (Raulin, 1965)

Although he does not seem to have very much faith in Scandinavian readers, Raulin's general attitude towards the book is quite positive. In both these reviews, de Beauvoir is portrayed as an intellectual and a philosopher. The image of the author as an intellectual is based on the translated text (the Danish one), which, as a nearly unabridged version, is treated more as a philosophical work than the subsequent severely abridged Norwegian version. When two of de Beauvoir's other books were translated and published in Norway in 1968

(L'existentialisme et la sagesse des nations and Les belles images), one journalist brought up the Danish translation of Le deuxième sexe, stating that a translation into Norwegian of this work would be very welcome because of its continued relevance ("Simone de Beauvoir", 1968).

The first Norwegian translation of Le deuxième sexe, Det annet kjønn was published in two volumes in 1970 (translated by Rønnaug Eliassen). This Norwegian version was both inspired by and in part based on the publication of the Danish translation (Solberg, 2016). On the occasion of a Norwegian translation, there was a renewed interest in the work and its 
author in the press as well as in some feminist magazines. For instance, the magazine Kvinner hjemme og ute (Women at Home and Abroad, published by the communist women's organization, the Norwegian Association of Women, of which the translator was a member) published a brief, positive review (“Lesekroken: Det annet kjønn”, 1970), as well as an excerpt from the book accompanied by an article on marriage written by the translator herself (Eliassen, 1970). In 1973, a new feminist magazine, Sirene (Siren), was launched, in which many references to de Beauvoir were made from the beginning and throughout its ten-year life span. ${ }^{9}$ Since Sirene aimed at being a platform for all factions of the women's rights movement in Norway, it had a wide-ranging readership, to whom de Beauvoir was - or became - familiar.

Most reviews of the 1970 Norwegian translation are found in the daily press. Many newspapers issued small notices repeating the exact same phrases, which were probably taken directly from the publishers' press statement, containing the following phrase or minor variations of it (and not much else): "Woman in our century: The classic work on woman in our century, The Second Sex by Simone de Beauvoir, comes out for the first time in Norwegian, in two volumes."10

In longer reviews, there were four recurring statements about the publication. Firstly, when commenting on the time gap between the French text and the translation (21 years), reviewers convey a mixture of the two following impressions - even within single reviews. On the one hand, parts of de Beauvoir's essay seem a bit outdated, in particular regarding the topic of sexuality. On the other, reviewers express surprise that the book is still so relevant. For instance, one reviewer writes that the chapter "The young girl" seems outdated, and at the same time, she states in the final paragraph: "I wish with all my heart that these books were not as relevant as they actually are!” (Førland, 1970). This somewhat confused impression may have been caused by the paradoxical omissions and downplaying of sexual content in the 
Norwegian translation, combined with paratextual elements emphasizing precisely that topic (Solberg, 2017a), a combination likely to cause unmet expectations.

Secondly, many reviewers mention de Beauvoir's relation to Sartre, for instance as "Sartre's famous (girl)friend" (Sandvik, 1970). Thirdly, they describe Le deuxième sexe as a classic or emphasize its central position as a point of reference, such as in the review entitled "A classic about women", where it is described as "one of the classics of feminist literature" (Lange-Nilsen, 1970). Fourthly, they discuss the omissions, expressing disappointment over the fact that the Norwegian translation was considerably abridged: about two-thirds of the book was cut (Solberg, 2017b). As one reviewer wrote:

It is a shame that when this classic work is now finally published in Norwegian, it happens to be as an abridged version. Admittedly with the consent of the author, but when the Norwegian Cultural Fund supports such an edition, should not the support be enough to give us the work in its entirety? In any case, we envy the Danish their elegant and complete three-volume edition. (Larsen, 1970)

Quite unanimously, the reviews of the Norwegian translation are positive in most respects, although noting the outdatedness of certain parts of the text and the abridgements. The author is still at this point strongly linked to Jean-Paul Sartre, but de Beauvoir the feminist also emerges as the publication is described as a "feminist" work.

Both the Danish translation in 1965 and the publication of the first Norwegian translation of Le deuxième sexe by Eliassen in 1970 affected the images of de Beauvoir. When the nearly unabridged Danish translation was discussed, the author was recurrently received as an intellectual. However, this aspect was downplayed in the reception of the Norwegian translation, which received predominantly positive, albeit somewhat confused reviews, in which the work was considered both outdated and relevant. In these reviews, a focus on my 
third category, de Beauvoir the feminist, comes to the fore. At the same time, definitions of her via her relation to Sartre are still common.

\section{The author image of de Beauvoir between the two Norwegian translations: 1975-1999}

De Beauvoir recurs as a point of reference in the literary magazine Vinduet (The Window) in 1976. During this year, which was the year after International Women's Year and still in the early stages of feminist literary studies, two feminist intellectuals referred to de Beauvoir in Vinduet. These were Irene Iversen, editor at the left-leaning publishing house Pax at the time (Pax published the translation of Le deuxième sexe in 1970), and later professor of women's literature, and Janneken Øverland, editor of Vinduet from 1980 to 1984, and later editor of translated literature at Gyldendal, a major Norwegian publishing house. In her article "How female authors and their works are treated in the literary milieu", Iversen questions the lack of female authors in the curricula of literary studies. She presents the example of a course in twentieth-century French literature at the University of Oslo, where at the time there were no female authors on the list, "despite the fact that France has significant female authors from this period, for instance Simone de Beauvoir" (Iversen, 1976). Øverland, in her article about how women are objectified through the gaze of male poets, asks how female readers of such poetry are supposed to identify with women in literature as anything but an objectified other, and she quotes de Beauvoir and Le deuxième sexe in a note to make her point clear (Øverland, 1976). These references, in addition to serving their concrete functions in the individual texts, also assert the image of the author as a feminist intellectual. It should, however, be noted that existentialist feminism was not especially popular among left-wing feminists at this time. In an article about the small book Hva er kvinnesak? (What is feminism?) by Kari Mundal Johnsen (1979), who discusses gender roles using the existentialist concepts of transcendence and immanence, Iversen (1980) states that Mundal Johnsen "is a true existentialist and an old- 
fashioned feminist!" Iversen further describes her as "more existentialist than Simone de Beauvoir, her teacher”, and in Iversen's view “[Mundal Johnsen]'s political perspective on women's issues as a whole is a step back both regarding de Beauvoir and regarding the women's movement we have seen over the last decade.” In other words, existentialist feminism was considered outdated, albeit understood as a necessary step on the way, and the analysis provided in Mundal Johnsen's book did not contribute to changing its status for the better.

Simone de Beauvoir died on April 14, 1986. Fallaize (1998, p. 7) points out that her death "commanded worldwide attention", and Norway was no exception. It is first and foremost de Beauvoir the feminist who was remembered in the obituaries in the press. These texts were primarily focused on her and Le deuxième sexe's impact on the women's rights movement: "Simone de Beauvoir is best known for her book 'The Second Sex', which had a great impact on women's liberation and feminist debate around the world" ("Den franske forfatterinnen", 1986). Some still defined her by her relation to Sartre, but at the same time recognized her achievements as author, philosopher and feminist:

It was on the day before the six-year anniversary of Jean-Paul Sartre's death on April 15,1980 , that his lifelong companion, the author, philosopher and feminist pioneer Simone de Beauvoir, passed away at the Cochin hospital in Paris. (Holte, 1986) Some texts include descriptions of her looks: "With her somewhat strictly pulled-back hair, she often sat for hours working [...] in the café Les Deux Magots” (Holte, 1986). Others discussed her personality:

Critics often said that she seemed distant, moody and unnecessarily theoretical when she spoke and wrote about women's issues [...] and she could seem unapproachable and arrogant to those not close to her. (“Den franske forfatterinnen", 1986) 
One obituary writer worthy of particular mention is translator Bente Christensen. At this point, Christensen had translated Une mort très douce (De Beauvoir, 1982), and she would later translate several other works by de Beauvoir, among them the retranslation of $L e$ deuxième sexe. In her very thorough obituary, published in the large and widely read conservative paper Aftenposten, Christensen discusses how existentialism according to de Beauvoir was different from existentialism according to Sartre, and describes de Beauvoir's journey from the bourgeoisie to an intellectual career. Christensen highlights Le deuxième sexe as the book that constituted de Beauvoir's "breakthrough" and points out her accomplishments as a memorialist, stressing that, as a "witness of her time", she went beyond the average autobiography (Christensen, 1986). Christensen's obituary of de Beauvoir is one of the most elaborate, and it paints a more complex author image, referring to de Beauvoir the feminist and de Beauvoir the author, as well as de Beauvoir the philosopher.

A few years later, in 1993, de Beauvoir's and Sartre's names occur together in a new context: unexpectedly (to this author at least), two fashion features use Sartre and de Beauvoir as a stylistic point of reference for the current fashion trends that year (Stemland, 1993; Hovland, 1993). Both allude to post-war France and the "smoke-filled cafés of Paris" where "intellectuals would meet with pen and paper", such as "Simone de Beauvoir and Jean-Paul Sartre, exponents of existentialism" (Stemland, 1993). This romanticized image of the two philosophers as a stylish café-going intellectual couple, drawn for the purpose of fashion features, suggests that the two have been properly assimilated into popular culture, and that at this point they have achieved a certain celebrity status.

In addition to the (literally) fashionable return of existentialism, several literary events also brought de Beauvoir back into the spotlight during the 1990s: in 1991, a committee voted Le deuxième sexe one of the hundred most influential books in Norway during the twentieth century, causing the re-publication of the translated book in a series called The Library of the 
Century in 1996 (Solberg, 2017b); a biography on Sartre was published (Østerberg, 1993), Toril Moi's biography of de Beauvoir came out in Norwegian (Moi, 1995), de Beauvoir's first autobiography, Mémoires d'une jeune fille rangée, came out in Norwegian translation (De Beauvoir, 1996), and de Beauvoir's letters to Nelson Algren were published in English (De Beauvoir, 1997). Furthermore, the Swedish author and journalist Åsa Moberg, who later (re)translated Le deuxième sexe into Swedish (De Beauvoir, 2002), wrote a book about de Beauvoir called Simone och jag (Simone and I), which came out in Norwegian translation in 1998. In the same year, Toril Moi published a collection of essays entitled Hva er en kvinne? (What is a woman?), in which de Beauvoir and her thinking are central (see Solberg, 2017b for more on Moi's contribution to the recognition of Simone de Beauvoir as a philosopher in her own right). While the English version, What is a woman? and other essays (Moi, 1999) is more than twice as long and is a scholarly edition, the Norwegian book clearly addressed a broader public. In addition to Moi, other Scandinavian academics working on philosophy contributed to the recognition of de Beauvoir the philosopher. Scholars such as Eva Gothlin, Else Wiestad, and Elin Svenneby were mentioned in the press in relation to their work on gender, philosophy and de Beauvoir (see Klem, 1994; Schedell, 1994; "Filosofiske kvinner", 1999), and the Norwegian scholars Annlaug Bjørsnøs (professor of French literature) and Tove Pettersen (professor of philosophy) worked continuously with de Beauvoir's works during this period. ${ }^{11}$

These events had a re-actualizing effect, and, being quite evenly distributed over only one decade, one can also assume that they influenced a change in status for the author. They may also have played a role in the initiation of a new and unabridged Norwegian translation that would appear in 2000 - for which the translator, Bente Christensen, was interviewed even before its publication (Larsen, 1999a). In articles, reviews and notices, among other things about these re-actualizing publications, de Beauvoir was regularly portrayed by using 
different combinations of the following four Fs (in Norwegian) fransk, feminist, filosof, forfatter - French, feminist, philosopher, author. ${ }^{12}$ The difference from her early reception is apparent, as de Beauvoir is now described mostly in terms of her work and accomplishments, rather than her personality or her relation to Sartre. However, there were still a few sexist descriptions of her, for instance as the "existentialist's mistress": "The French existentialist Jean-Paul Sartre was not particularly interested in sex, according to the letters signed by his mistress Simone de Beauvoir" ("Den franske eksistentialist Jean-Paul Sartre...”, 1997), or as his girlfriend: "manuscripts by the existentialist philosopher and author Jean-Paul Sartre and de Beauvoir, who was his girlfriend throughout a long and active life" (“Eksistentialistmanuskripter som arveavgift", 1989). Despite these latter examples, the 1980s and 1990s showed a development, particularly in regard to the author's status as a recognized intellectual.

\section{The era of the Norwegian retranslation of Le deuxième sexe: 2000-2010}

At the core of the translation-studies perspective on reception is the question of why a certain text is translated and why it appears at a certain point in time. This is a particularly important question with regard to retranslations, i.e. "a second or later translation of the same source text into the same target language" (Koskinen \& Paloposki, 2010, p. 294), since there is presumably always a reason for it being translated again. The reasons for retranslating $L e$ deuxième sexe into Norwegian are arguably complex, comprising both textual and contextual factors. Textual factors of particular interest are features of the first translation, such as the omission of large parts of the text, and changes in how the existentialist vocabulary is expected to be translated into Norwegian (see Solberg, 2017a and 2017b). The omissions in the first translation were in part ideologically conditioned, and should be seen in light of the viewpoint of the translator, a feminist of the "old school", perhaps less focused on the topic of 
sexuality (Solberg, 2017a). Both these textual features are indeed connected to contextual factors, such as the emergence of a new readership in both current and former students of philosophy and gender studies - expecting more precise and consistent translations of the existentialist vocabulary - and to changing translational norms, towards expectations of closeness to the source text (see Solberg, 2017b). These "new" expectations of a Norwegian translation of this work are further influenced by changes in the author's status, as I have noted elsewhere (Solberg, 2017b).

The renewed interest in de Beauvoir during the 1990s continued into the new millennium. When the retranslation came out in 2000, both the translator, Bente Christensen, and Toril Moi, who wrote an introductory essay for it, were interviewed in the press about the publication (Moestue Bugge, 2000; Emberland, 2000). Christensen focused in her interview on the work's continued relevance, which was also a recurring argument in reviews of the retranslation (Moestue Bugge, 2000; Larsen, 2000; Solberg, 2000). The reviews, although there were not many of them, were almost exclusively positive. Many focused on the completeness of the retranslation (Emberland, 2000; Larsen, 2000; Moestue Bugge, 2000; Skre, 2000; Solberg, 2000; Øyan, 2000; see also Solberg, 2017b), and attention was also drawn to the reading public's positive response and impressive sales figures, as in the article "We are flocking to de Beauvoir's source of feminism" (Skre, 2000).

Another literary event drew attention to de Beauvoir's thought and work just after the publication of the retranslation. Moi's book Jeg er en kvinne. Det personlige og det filosofiske (I am a woman: The personal and the philosophical) was published in 2001. In this text, Moi analyses de Beauvoir's style in Le deuxième sexe, arguing for the place and potential of the personal in philosophy. The book received positive attention in the press, and Moi's work on de Beauvoir regained media attention the following year when Moi was awarded an honorary 
doctorate at the University of Bergen in Norway (See Nilsen, 2001; Økland, 2001; Wold, 2001; Lindgren, 2001).

In the wake of the retranslation of Le deuxième sexe (2000) and I am a woman (2001), four of de Beauvoir's other books were published in Norwegian, all translated by Christensen: La force de l'âge (2004), L'Amérique du jour le jour (2005), L'Invitée (2006), and Pyrrhus et Cinéas - Pour une morale de l'ambiguïté (2009). When Christensen won a translation award in 2007, her work on books by de Beauvoir was highlighted ("Bokklubbane heidrar omsetjarar", 2007), signalling the now high status associated with this author (see also Solberg, 2017b).

In 2004, the feminist magazine Fett was launched, aimed at a new generation of young feminists (the title, Fett, is an acronym for "feministisk tidsskrift", i.e. "feminist magazine" carrying different meanings, such as Grease, Cool and in some dialects Pussy-owned by the radical feminist organization Kvinnefronten, the Women's Front of Norway). It quickly became popular, and soon had a print run of 4,000 copies (H. L. Fossum, Fett's editor in chief from 2015 to present (2017), personal communication, February 3, 2017). In Fett, de Beauvoir was a self-evident point of reference from the very first issue and throughout the decade. In fact, there are mentions of her in practically every issue of this decade, often as a side note, but from time to time also as the main focus. For instance, de Beauvoir is the topic of an editorial (Engh Førde, 2006), and the retranslation of Le deuxième sexe is revisited in the main literary column (Kvamme Fredriksen, 2009).

De Beauvoir's high status as a point of reference for intellectuals, artists and women in leading positions becomes apparent during the 2000s. When asked "What is the best book you have read?" or "What book has affected you the most?" answering "Le deuxième sexe" is far from uncommon. "De Beauvoir" is also a frequent answer to the following types of question: "Who is your role model?", "What historic person do you identify with?" or even 
"Who would you like to share a meal with?" - for young left-wing feminists in the cultural or literary field as well as established female (business) leaders. ${ }^{14}$ De Beauvoir's name is thus highly valued as a sign of cultural capital (in the Bourdieusian sense, as described by Scott and Marshall, 2009) at the turn of the millennium. This might have been caused simply by the retranslation's effect as a reminder of the work's existence, since these answers appear after 2000 (with only one exception in my material - a short questionnaire without title or author from 1996). However, de Beauvoir's value as cultural capital should also be understood in light of her recognition as an intellectual, to which the above-mentioned publications added.

On January 9, 2008, the centenary of de Beauvoir's birth was celebrated worldwide. This was also the case in Norway by, among others, writers and journalists, particularly in the left-wing newspaper Klassekampen, which ran five pieces about her on that day (notices and interviews, plus an excerpt from the Norwegian translation of America Day by Day). ${ }^{15}$ In one of the largest popular newspapers in the country, Dagbladet, an article praising de Beauvoir and asserting her position as philosopher and feminist was printed: "A hundred years after she was born, Simone de Beauvoir stands out in the starry sky of philosophy as the creator of modern feminism and the quintessence of an intellectual woman" (Michelet, 2008).

\section{Concluding remarks}

From the things that have been written about de Beauvoir in Norway, one can discern that the author images of her change over time. Painting with somewhat broad strokes, we can say that, during the 1940s and 1950s, she was perceived as a well-known existentialist, but remained in the shadow of Sartre. In the 1960s, it was de Beauvoir the author - or memorialist, to use Fallaize's term - who was of interest, yet she was still strongly connected to Sartre. Through the image of Sartre's de Beauvoir, she gained recognition as an author and intellectual. Later, a greater interest in de Beauvoir the feminist arose; these images led to a 
demand for the first Norwegian translation of Le deuxième sexe, which came out in 1970. This translation in itself confirmed the image of de Beauvoir the feminist.

Although de Beauvoir was initially associated with existentialism, it took several decades for her to become recognized as a philosopher in her own right in Norwegian print media. Moi states in Textual/Sexual Politics (Moi, 1985, p. 98): “[...] existentialism in general was marginalized by the shift to structuralism and post-structuralism in the 1960s." Later she also pointed out:

In the 1970s and 1980s French intellectual fashions (structuralism, poststructuralist, Lacanian psychoanalysis, postmodernism) left no space at all for an unreconstructed existentialist humanist of Beauvoir's type. (Moi, 1994, p. 76)

But, as I have shown in this article, the impression of existentialism as outdated changed during the 1990s, and it became (literally) fashionable again. As several scholars insisted on her philosophical contribution, the image of de Beauvoir the philosopher developed, alongside the images of de Beauvoir the author and de Beauvoir the feminist, thus preparing the ground for a retranslation of her most significant philosophical work. With the availability of the retranslation of Le deuxième sexe into Norwegian, it became possible for a wider Norwegian readership to valorise de Beauvoir as a philosopher. One could even gain cultural capital from mentioning her name and her main work. Soon, knowing who - and what - she was became part of general knowledge.

The interplay between the images of de Beauvoir in Norwegian print media and the Norwegian translations of Le deuxième sexe outlines a long journey in which she starts out as a marginalized, and soon outdated, disciple of Sartre and - through the work of scholars, translators, journalists and publishers - ends up as a recognized author and memorialist, a significant philosopher and popular feminist icon. 


\footnotetext{
${ }^{1}$ There is also a translation into English from 1953 that linguistically would have been accessible to many Norwegian readers, but from my material it does not seem to have had any notable impact on the Norwegian reception.
}

${ }^{2}$ H. M. Parshely's translation into English was an abridged version, which has been criticized by philosophy scholars like Margaret Simons and Toril Moi (see Simons, 1983; Moi, 2002).

${ }^{3}$ I examined the following magazines during the process of collecting data: Vinduet, Vagant, NKN's blad, Kvinner hjemme og ute, Sirene, Kvinnefront, Fett, Kvinner og klфr, Kvinnefronten, Vi er mange, Kvinns, Lavendelekspressen, Norges bondekvinnelags blad, Kvinnen og Tiden, and Kjerringråd.

${ }^{4}$ My searches in NB Digital yielded hits in Arbeiderbladet, Halden arbeiderblad, Nordlands avis, Svalbardposten, Hardanger, Firda folkeblad, Altaposten, Dagsavisen, and Rogalands avis. In Retriever, my searches resulted in hits from Klassekampen, Dagsavisen, Morgenbladet, Bergens tidende, Aftenposten, Dag og Tid, Romsdals budstikke, Moss avis, VG, Stavanger Aftenblad, Dagbladet, Dagens Naringsliv, Ny tid, Nationen, Adresseavisen, Nordlys, Sunnmфrsposten, Fredrikstads blad, Fadrelandsvennen, and Økonomisk rapport. It should be noted that this database does not include all volumes and years of all the different papers.

${ }^{5}$ In ARBARK, there were clippings from Romsdalsposten, Bergens arbeiderblad, Rogalands avis, Demokraten, Bergens tidende, Finnmarken, Fremtiden, Romsdals folkeblad, Tidens krav, Sunnmфre arbeideravis, Arbeiderbladet, Orientering, Vårt blad, Moss dagblad, Adresseavisen, Gudbrandsdølen, Folkets framtid, Frisprog, Aftenposten, Porsgrunns dagblad, and Teledølen.

${ }^{6}$ The search also included misspellings, such as: Bauvoir, Bauvoire, Beavoir, Beauvar, Beuvoire and Beauvoire. ${ }^{7}$ All translations into English are mine.

${ }^{8}$ The feminine form of "friend" also changes meaning some time during the period in question, from girlfriend to female friend. Initially, it is often not quite clear whether it carries both meanings, or just the latter. It is marked in the text when it is open for interpretation.

${ }^{9}$ For an analysis of Sirene's role and history see Synnøve Skarsbø Lindtner, 2016.

${ }^{10}$ To my knowledge, these are: Romsdalsposten (January 29, 1970); Bergens arbeiderblad (January 29, 1970); Rogalands avis (January 30, 1970); Demokraten (February 3, 1970); Bergens tidende (February 11, 1970); Finnmarken (February 14, 1970); Dagbladet (February 17, 1970); Fremtiden (February 21, 1970); Romsdals folkeblad (February 24, 1970); Tidens krav (February 24, 1970); Sunnmфre arbeideravis (February 25, 1970); 
Arbeiderbladet (February 26, 1970); Demokraten (February 28, 1970); Orientering, (February 28, 1970); Moss dagblad (March 5, 1970); Moss Avis (March 10, 1970); Dag og tid (March 11, 1970); and Arbeiderbladet (March 13, 1970).

${ }^{11}$ Their work culminated in the publication Simone de Beauvoir: A Humanist Thinker (Bjørsnøs \& Pettersen, 2015), which received much attention, both within and outside of academia, and drew a massive crowd for its launch at one of Oslo's biggest (although too small for this event) and most popular literary venues, BLÅ. ${ }^{12}$ See Borud, 1988; Borud, 1991; Landro, 1992; Olaussen, 1993; Borud, 1993; Straume, 1994; Håbjørg, 1994; Bratholm, 1996; Larsen, 1996; Lending, 1997; Larsen, 1999b.

${ }^{13}$ See, for instance, Folkvord, 2004; Mauno, 2004; Lunder Bredvold, 2004; "På nattbordet", 2004a; "På nattbordet”, 2004b; Pedersen, 2004; Thorvaldsen, 2005; Nielsen, 2005; Jonger, 2006; “På nattbordet”, 2006; "Sandnes' fem favoritter", 2007; "Morgenbladets bibliotek", 2007; "På nattbordet”, 2007; Grønneberg, 2007; Hovde, 2008; Brox, 2009; Brostrup Müller, 2009; Hjorth, 2009; Ulstein, 2009; "Hilde Marie Farstad Bergersen”, 2010; Mauno, 2010; “Hjemmekjær moteprinsesse”, 2010.

${ }^{14}$ See Brügger Bjånesøy, 2001; Øveraas, 2001; Farbrot, 2002; Løvik, 2002; “Røtter: Bitte Kverum”, 2002;

Tjernshaugen, 2002; Spets, 2004; Brøyn, 2004; Larsen, 2009.

${ }^{15}$ These were: De Beauvoir, 2008; Jordheim Larsen, 2008; Jordheim Larsen \& Haugen, 2008; Lilleb $\varnothing, 2008$, and a notice with unknown author. 


\section{References}

12 på strak arm [12 offhand]. (2008, January 11). Dagsavisen.

Antikommunistisk kunstfest i Paris [Anti-communist art party in Paris]. (1952, May 2). VG.

Bokklubbane heidrar omsetjarar [The book clubs honour translators]. (2007, June 6). Nationen.

Borud, H. (1988, November 15). Verdikrise? I etisk ingenmannsland [Crisis of values? In an ethical no-man's land]. Aftenposten.

Borud, H. (1991, April 2). Kjært ekko fra Gidskes elskede 50-talls-Paris [Cherished echo from Gidske's beloved 1950s Paris]. Aftenposten.

Borud, H. (1993, October 26). Sartrebok for rester av den dannede almenhet [Book on Sartre for remnants of the educated public]. Aftenposten.

Bratholm, E. (1996, April 14). Det siste tabu [The last taboo]. $V G$.

Brostrup Müller, O. (2009, May 23). En småbrydd festspilldikter [A slightly embarrassed festival poet]. Klassekampen.

Brox, J. (2009, January 3). Outsideren fra Bergen [The outsider from Bergen]. Klassekampen.

Brügger Bjånesøy, K. (2001, August 25). Kvinner i kamp [Women in battle]. Dagbladet.

Brøyn, M. B. (2004, September 4). Ord om annet: Bare må ha det [Words in passing: Have to have it]. Aftenposten.

Christensen, B. (1986, April 17). Et hovedvidne til vår tid [A major witness of our time]. Aftenposten.

De Beauvoir, S. (1949). Le deuxième sexe I: Les faits et les mythes [The Second Sex I: Facts and Myths]. Paris: Gallimard.

De Beauvoir, S. (1949). Le deuxième sexe II: L’expérience vécue [The Second Sex II: Lived Experience]. Paris: Gallimard.

De Beauvoir, S. (1953). The Second Sex. (H. M. Parshley, Trans.). London: Jonathan Cape.

De Beauvoir, S. (1965a). Det andet køn 1: Kendsgerninger og myter [The Second Sex 1: Facts and Myths]. (K. Stougård Hansen, Trans.). Copenhagen: Gyldendal.

De Beauvoir, S. (1965b). Det andet køn 2: Erfaringer og oplevelse: I. del [The Second Sex 2: Lived Experience: part I]. (K. Stougård Hansen \& S. Johansen, Trans.). Copenhagen: Gyldendal.

De Beauvoir, S. (1965c). Det andet kфn 3: Erfaringer og oplevelse: II. del [The Second Sex 3: Lived Experience: part II]. (S. Johansen, Trans.). Copenhagen: Gyldendal. 
De Beauvoir, S. (1968). Eksistensialismen og den borgerlige snusfornuft [Existentialism and the Bourgeois Commonsense]. (Ivar M. Ravnum, Trans.). Oslo: Cappelens forlag.

De Beauvoir, S. (1968) Når masken faller [When the mask falls]. (Margaret Herberg, Trans.). Oslo: Gyldendal. De Beauvoir, S. (1970a). Det annet kjønn 1 [The second sex 1]. (R. Eliassen, Trans.). Oslo: Pax.

De Beauvoir, S. (1970b). Det annet kjønn 2 [The second sex]. (R. Eliassen \& A. Kittang, Trans.). Oslo: Pax. De Beauvoir, S. (1982). En lett og rolig d $\phi d$ [A very easy death]. (B. Christensen, Trans.). Oslo: Solum.

De Beauvoir, S. (1996). En veloppdragen ung pikes erindringer [Memoirs of a dutiful daughter]. Oslo: Pax.

De Beauvoir, S. (2000). Det annet kjønn [The second sex]. (B. Christensen, Trans.). Oslo: Pax.

De Beauvoir, S. (2002). Det andra könet [The second sex]. (Åsa Moberg \& Adam Inczèdy-Gomboso, Trans.). Stockholm: Norstedt.

De Beauvoir, S. (2004). Moden alder [The prime of age]. (B. Christensen, Trans.). Oslo: Pax.

De Beauvoir, S. (2005). Amerika fra dag til dag [America day by day]. (B. Christensen, Trans.). Oslo: Pax.

De Beauvoir, S. (2006). Gjesten [She came to stay]. (B. Christensen, Trans.). Oslo: Pax.

De Beauvoir, S. (2008, January 9). En flenge midt i byen [A gash in the heart of the city]. (B. Christensen, Trans.). Klassekampen.

De Beauvoir, S. (2009). Pyrrhos og Cineas - Tvetydighetens etikk [Pyrrhus and Cineas - The ethics of ambiguity]. (B. Christensen, Trans.). Oslo: Pax.

Den franske eksistensialist Jean-Paul Sartre... [The French existentialist Jean-Paul Sartre...]. (1997, February 23). $V G$.

Den franske forfatterinnen Simone de Beauvoir døde mandag [The French authoress Simone de Beauvoir died Monday]. (1986, April 14). NTB.

Dette og Hint [This and that]. (1948) Vinduet, 6, p. 405.

Eksistensialistmanuskripter som arveavgift [Existentialist manuscripts as inheritance tax]. (1989, September 16). Aftenposten.

Eliassen, R. (1970). Lovverk og lappverk [Legislation and patchwork]. Kvinner hjemme og ute [Women at home and abroad], 4, pp. 3-5.

Emberland, T. (2000, April 29). En feministisk klassiker [A feminist classic]. Nordlys.

Engh Førde, K. (2006). Ikonet [The Icon]. Fett, 2, p. 5.

Fallaize, E. (1995). Reception problems for women writers: The case of Simone de Beauvoir. In D. Knight \& J. Still (Eds.), Women and Representation (pp. 43-56). London: WIF. 
Fallaize, E. (1998). Simone de Beauvoir: A Critical Reader. Routledge: London.

Farbrot, A. (2002, April 18). Ferske fjes: Kvinnekraften i Elkem [Fresh faces: Female power in Elkem]. $\emptyset$ konomisk rapport.

Filosofiske kvinner [Philosophical women]. (1999, May 10). Dagsavisen.

Folkvord, M. (2004, March 8). Tre på 8. Mars [Three on March 8]. Klassekampen.

Førland, B. K. B. (1970, April 23). Det annet kjønn [The second sex]. Rogalands avis.

Glimt fra Frankrike [Glimpses from France]. (1948). Vinduet, 9, p. 685.

Grønneberg, A. (2007, November 1). Martine Aurdal (29). Dagbladet.

Hilde Marie Farstad Bergersen. (2010, March 6). Romsdals budstikke.

Hjemmekjær moteprinsesse [Home-loving fashion princess]. (2010, July 30). Bergens Tidende.

Hjorth, V. (2009, October 16). Talentet kaller på voldtekten [Talent calls for rape]. Morgenbladet.

Holte, E. (1986, April 15). Simone de Beauvoir død [Simone de Beauvoir is dead]. Aftenposten.

Hovde, K. (2008, September 27). På lag med Hagen [On Hagen’s team]. Adresseavisen.

Hovland, K. (1993, August 16). Moteriktig når høsten kommer [Fashionable when autumn arrives]. VG.

Håbjørg, A. V. (1994, August 19). En høst med Mykle [An autumn with Mykle]. VG.

Iversen, I. (1976). Hvordan kvinnelige forfattere og deres verk blir behandlet i det litterære miljøet [How female authors and their works are treated in the literary milieu]. Vinduet, 1, pp. 40-48.

Iversen, I. (1980). Boka alle leser - men ingen vil snakke om [The book everyone reads - but no one wants to talk about]. Sirene, 3 .

Jean-Paul Sartre og frue i Oslo [Jean-Paul Sartre and wife in Oslo]. (1951, June 16). VG.

Jean-Paul Sartres [Jean-Paul Sartre's]. (1958, December 4). VG.

Jonger, R. (2006, September 5). Vil bare være meg selv nå! [I just want to be myself now!]. Dagsavisen.

Jordheim Larsen, Ch. (2008, January 9). Simone de Beauvoirs største fan [Simone de Beauvoir's biggest fan]. Klassekampen.

Jordheim Larsen, Ch. \& Haugen, K. (2008, January 9). Beauvoir på godt og vondt [Beauvoir for better or worse]. Klassekampen.

Klem, C. (1994, June 18). - Hun var aldri løperjente [- She was never an office girl]. Arbeiderbladet.

Koskinen, K. \& Paloposki, O. (2010). Retranslation. In Y. Gambier \& L. v. Doorslaer (Eds.), Handbook of Translation Studies, vol. 1, (pp. 294-298). Amsterdam: John Benjamins.

Kvamme Fredriksen, I. (2009). Farlig og revolusjonerende [Dangerous and revolutionary]. Fett, 1-2, pp. 10-11. 
Landro, J. H. (1992, October 17). Bryt faggrensene! [Break down the disciplinary barriers!]. Bergens Tidene.

Lange-Nilsen, S. (1970, June 8). En klassiker om kvinner [A classic about women]. Aftenposten.

Larsen, M. (2009, July 28). Lyden av tordenvær [The sound of thunderstorms]. Dagsavisen.

Larsen, P. (1970, March 9). Det annet kjønn [The second sex]. Arbeiderbladet.

Larsen, T. (1996, May 8). Sannhet gjennom fiksjon: Åsa Mobergs møte med Simone de Beauvoir [Truth through fiction: Åsa Moberg’s meeting with Simone de Beauvoir]. Arbeiderbladet.

Larsen, T. (1999a, January 15). Feminismens bibel fyller 50 år [The feminist bible turns 50]. Dagsavisen.

Larsen, T. (1999b, June 2). Intellektuell forelskelse [Intellectual love affair]. Dagsavisen.

Larsen, T. (2000, April 26). -Boka som forandret livet mitt. «Det annet kjønn» endelig oversatt til norsk [The book that changed my life. "The Second Sex" finally translated into Norwegian]. Dagsavisen.

Lending, M. (1997, October 15). Dobbelt sjalusidrama [Double jealousy drama]. Aftenposten.

Lesekroken: Det annet kjønn [The reading corner: The second sex]. (1970). Kvinner hjemme og ute, 4.

Lillebø, S. (2008, January 9). Sjokkerende Simone [Shocking Simone]. Klassekampen.

Lindgren, L. (2001, June 13). På filosofisk stjernevisitt [A philosophical star visits]. Dagens Naringsliv.

Lunder Bredvold, H. (2004, March 13). Bare må ha det liker rare folk og lakris [Have to have it likes strange people and liquorice]. Aftenposten.

Løvik, O. A. (2002, February 17). Venter flom av kvinnelige ledere [Expects wave of female leaders].

Aftenposten.

Macé, N. (1961, February 9). En forfatter søker seg selv: Simone de Beauvoirs memoarer [An author in search of herself: Simone de Beauvoir's memoirs]. $V G$.

Macé, N. (1964, February 21). Med mot og smertelig klarsyn [With courage and painful clear-sightedness]. VG.

Mauno, H. (2004, March 10). - Vil helst være en katt [- Would prefer being a cat]. Dagsavisen.

Mauno, H. (2010, June 11). Navn i nyhetene [Name in the news]. Dagsavisen.

Michelet, M. (2008, January 9). Angst. Og glede [Anxiety. And joy]. Dagbladet.

Moberg, Å. (1998). Simone og jeg [Simone and I] (E. Kolstad, Trans.). Oslo: Oktober.

Moestue Bugge, E. (2000, April 18). Over 50 år siden Simone de Beauvoir utga "Det annet kjønn": Feminismeklassiker endelig på norsk [Over 50 years since Simone de Beauvoir published "The second sex": Feminist classic finally in Norwegian]. Aftenposten.

Moi, T. (1985). Textual/sexual politics: Feminist literary theory. London: Methuen.

Moi, T. (1994). Simone de Beauvoir: The making of an intellectual woman. Blackwell: Oxford. 
Moi, T. (1995). Simone de Beauvoir - en intellektuell kvinne blir til [Simone de Beauvoir: The making of an intellectual woman]. Oslo: Gyldendal.

Moi, T. (1998). Hva er en kvinne? Kjфnn og kropp i feministisk teori [What is a woman? Gender and body in feminist theory]. (R. Ch. Granaas, Trans.). Oslo: Gyldendal.

Moi, T. (1999). What is a woman? And other essays. Oxford: Oxford University Press.

Moi, T. (2001). Jeg er en kvinne: Det personlige og det filosofiske [I am a woman: The personal and the philosophical]. Oslo: Pax.

Moi, T. (2002). While we wait: The English translation of The second sex. Signs, 27 (4), 1005-1035.

Morgenbladets bibliotek [Morgenbladet’s library]. (2007, July 13). Morgenbladet.

Mundal Johnsen, K. (1979). Hva er kvinnesak? [What is feminism?] Oslo: Gyldendal.

Nielsen, A. (2005, March 4). Vekker med blinkende mobil [Wakes up with flashing mobile]. Dagsavisen.

Nilsen, G. J. (2001, July 4). Sunn fornuft og kritisk sans [Common and critical sense]. Bergens Tidende.

Olaussen, L. M. (1993, February 17). Søkelys: Kvinner [Spotlight: Women]. Nordlys.

Pedersen, P. E. (2004, September 10). Det unødvendige er aske [The unnecessary is ashes]. Dagsavisen.

Pettersen, T. \& Bjørsnøs, A. (2015). Simone de Beauvoir: A humanist thinker. Leiden: Brill.

På nattbordet [On the nightstand]. (2004a, August 26). Dagens Naringsliv.

På nattbordet [On the nightstand]. (2004b, October 18). Dagens Naringsliv.

På nattbordet [On the nightstand]. (2006, June 29). Dagens Naringsliv.

På nattbordet [On the nightstand]. (2007, August 16). Dagens Naringsliv.

Raulin, A. (1965, June 10). Grunnbok i kvinnelivets elendighet [Primer on the misery of women's lives]. $V G$.

Russ, J. (1984). How to suppress women's writing. University of Texas.

Røtter: Bitte Kverum [Roots: Bitte Kverum]. (2002, February 28). Økonomisk rapport.

Sandnes' fem favoritter [Sandnes' five favorites]. (2007, March 24). Dagbladet.

Sandvig, S. (1970, April 30). Det annet kjønn? [The second sex?]. Gudbrandsdølen.

Schedell, I. (1994, July 2). Kjønnskamp i bakspeilet [Gender struggle in the rear-view mirror]. Arbeiderbladet.

Schmid, W. (2009). Implied author. In P. Hühn, J. Pier, W. Schmid, \& J. Schönert (Eds), Handbook of narratology, (pp. 161-173). Berlin: Walter de Gruyter.

Scott, J. \& Marshall, G. (2009). Cultural capital. A Dictionary of Sociology. Oxford University. Retrieved February 9, 2017, from 
http://www.oxfordreference.com/view/10.1093/acref/9780199533008.001.0001/acref-9780199533008$\underline{\mathrm{e}-474 .}$

Simone de Beauvoir. (1968, August 28). Arbeiderbladet.

Simons, M. (1983). The silencing of Simone de Beauvoir: Guess what's missing from The second sex. Women's Studies International Forum, 6 (5), 559-564.

Skarsbø Lindtner, S. (2014). "Som en frisk vind gjennom stuen”: Kvinnebladet Sirene (1973 - 1983) og det utvidete politikkbegrepet. ["Like a fresh wind through the living room" The women's magazine Sirene (1973-1983) and the expanded notion of politics] (PhD thesis). University of Bergen, Norway.

Skre, A. (2000, June 4). Vi strømmer til Beauvoirs feminismekilde [We are flocking to Beauvoir's source of feminism]. Aftenposten.

Solberg, I. H. (2016). Finding the X-factor: Support translation and the case of Le Deuxième Sexe in Scandinavia. In T. Rautaoja, K. Koskinen \& T. Mikolič Južnič (Eds.), New Horizons in Translation Research and Education 4 (pp. 86-114). University of Eastern Finland.

Solberg, I. H. (2017a). Clashing methods, common goals? Negotiating ideology in the Norwegian translation of Le deuxième sexe from 1970. In I. Herrero López, C. Alvstad, J. Akujärvi \& S. Lindtner (Eds.), Gender, Translation and Transnational Reception. Montreal: Collection Vita Traductiva, Éditions Québécoises de l'Euvre. In press.

Solberg, I. H. (2017b). The voice of the implied author in the first Norwegian translation of Simone de Beauvoir's Le deuxième sexe. In C. Alvstad, A. Greenall, H. Jansen \& K. Taivalkoski-Shilov (Eds.), Textual and Contextual Voices of Translation. Amsterdam: John Benjamins. In press.

Solberg, T. (2000, May 10). Kvinnelig klassiker [Female classic]. Dagens Naringsliv.

Spets, K. (2004, August 22). - Hva ville livet vært uten norsk film, Petronella Barker? [-What would life be without Norwegian film, Petronella Barker?]. $V G$.

Stemland, J. H. (1993, February 22). Motetrend med mørke toner [Fashion trend with dark tones]. VG.

Straume, A. Ch. (1994, March 5). Likestillingens mor [The mother of equality]. Aftenposten.

Thorvaldsen, P. (2005, January 27). Sommeren med Simone [The summer with Simone]. Bergens Tidende.

Tjernshaugen, K. R. (2002, December 1). Anbefaler snømenn [Recommends snowmen]. Dagsavisen.

Ulstein, J. O. (2009, October 30). Kjønnsrollene og røyndommen [Gender roles and reality]. Dag og tid.

Under leselampen [Under the reading lamp]. (1965). NKN’s blad, 5.

Ustvedt, Y. (1961). Simone de Beauvoir ser tilbake [Simone de Beauvoir looks back]. Vinduet, 1, pp. 16-22. 
Wold, B. (2001, June 13). Jeg'et og filosofien [The self and philosophy]. Klassekampen.

Økland, I. (2001, June 29). Utfordrende essay fra Toril Moi [Challenging essay from Toril Moi] Aftenposten.

Østerberg, D. (1993). Jean-Paul Sartre: filosofi, kunst, politikk, privatliv [Jean-Paul Sartre: Philosophy, art, politics, personal life]. Oslo: Gyldendal.

Øveraas, T. (2001, November 1). Kjendisspekket premiere [Celebrity packed premiere]. VG.

Øverland, J. (1976). Solbeveget svermerske eller madam på Moss [Romantic moved by the sun, or madam in Moss]. Vinduet, 3, pp. 30-39.

Øyan, T. G. (2000, April 29). Den evige toer [Forever number two]. Dagsavisen. 